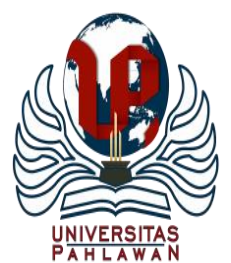

Edukatif : Jurnal Ilmu Pendidikan Volume 3 Nomor 2 Tahun 2021 Halm 619 - 630 EDUKATIF: JURNAL ILMU PENDIDIKAN

Research \& Learning in Education

https://edukatif.org/index.php/edukatif/index

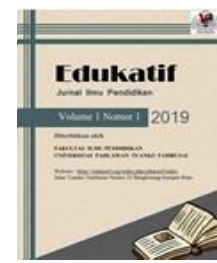

\title{
The Effect of Indirect Coded Versus Indirect Non-Coded Corrective Feedback on Improving Students' Grammatical Accuracy of EFL Writing Class
}

\author{
Maksimilianus Doi $^{1 \times}$, Fransiskus Maria Separ ${ }^{2}$, Febe F. Irawati Wanggai ${ }^{3}$ \\ Universitas Flores, Indonesia ${ }^{1,2,3}$ \\ E-mail: $\underline{\text { macksydtory @ gmail.com }}{ }^{1}, \underline{\text { hanz fms @ gmail.com }}^{2}$, fheiralexon@gmail.com $^{3}$
}

\begin{abstract}
Abstrak
Penelitian ini bertujuan untuk menginvestigasi keefektifan umpan balik tidak langsung kode dan bukan kode dalam meningkatkan ketepatan tata bahasa pada mahasiswa Jurusan Bahasa Inggris Universitas Flores semester 4 tahun akademik 2019/2020. Penelitian ini merupakan eksperimen semu dengan pretest-posttest nonequivalent design. 54 mahasiswa, sebagai sampel penelitian, tiga kelas utuh dengan 18 siswa di masing-masing kelas ditentukan secara acak menjadi tiga kelompok, yaitu kelas umpan balik tidak langsung kode, bukan kode, dan kelas kontrol. Menulis bebas merupakan sumber utama data. Skema penilaian dilakukan berdasarkan lima kategori, yakni isi, organisasi, kosakata, penggunaan bahasa, dan mekanik. Reliabilitas instrumen dinilai dengan teknik antar penilai. Data dianalisis menggunakan ANCOVA dilanjutkan dengan uji Scheffe. Hasil penelitian menunjukkan bahwa; (1) Ada perbedaan keefektifan antara umpan balik tidak langsung kode dan bukan kode dalam meningkatkan ketepatan tata bahasa pada tulisan kedua, (2) Umpan balik tidak langsung kode lebih efektif dibandingkan umpan balik tidak langsung bukan kode, dan dengan kelas kontrol pada tulisan kedua, (3) Ada perbedaan keefektifan umpan balik kode dan bukan kode dalam meningkatkan ketepatan tata bahasa pada tulisan baru, (4) Umpan balik tidak langsung kode lebih efektif dibandingkan dengan umpan balik bukan kode, dan dengan kelas kontrol pada tulisan baru.
\end{abstract}

Kata kunci: keefektifan, umpan balik koreksi berkode tidak langsung, umpan balik koreksi tidak berkode tidak langsung, ketepatan tata bahasa, pengoreksian sendiri.

\begin{abstract}
The aimed at investigating the effectiveness of indirect coded CF and indirect non-coded CF on improving grammatical accuracy at the fourth semester students of English Literature Study Program Flores University in 2013/2014. This research was quasi-experiment with pre-test-post-test non-equivalent design. As the sample, 54 students in three intact classes with 18 students of each class were randomly assigned to three groups; indirect coded CF, indirect non-coded $C F$, and control groups. Free writing was the major source of data. The scoring scheme adopted based on the five categories; content, organization, vocabulary, language use, and mechanics. The instrument reliability was assessed by the inter-rater technique. ANCOVA was to analyze data continued by post-hoc Scheffe. The upshots denote that (1) indirect-coded $C F$ and indirect non-coded $C F$ have a significant difference of effectiveness on grammatical accuracy in the second draft with self editing strategy: (2) indirect coded CF is more effective than indirect non-coded CF, and that of control group in the second draft with self-editing strategy; (3) indirect coded CF and indirect non-coded CF have a significant different in a new draft; (4) indirect coded CF is more effective than indirect non-coded CF, and that of control group in a new draft.
\end{abstract}

Keywords: effect, indirect coded corrective feedback, indirect non-coded corrective feedback, grammatical accuracy, self-editing.

Copyright (c) 2021 Maksimilianus Doi, Fransiskus M. Separ, Febe F. Irawati Wanggai

$\triangle$ Corresponding author

Email : macksydtory@gmail.com

DOI : https://doi.org/10.31004/edukatif.v3i2.365 
620 The Effect of Indirect Coded Versus Indirect Non-Coded Corrective Feedback on Improving Students' Grammatical Accuracy of EFL Writing Class-Maksimilianus Doi, Fransiskus M. Separ, Febe F. Irawati Wanggai

DOI: https://doi.org/10.31004/edukatif.v3i2.365

\section{BACKGROUND}

For most students, writing is an extremely difficult task if they are trying to grapple in their language with new ideas and new ways of looking at them. Writing is a product-constructed from the writer's command of grammatical knowledge, and regarded as an extension of grammar (Ayuba \& Widodo, 2015), a means of reinforcing language patterns through habit formation and testing learners' ability to produce well-formed novel sentences. The ability to write is the competency or skill in expressing attractively ideas or thought in writing form (Larasati, 2021). Therefore, Writing is one of the most important skills in teaching English as a foreign language. It reflects the power of students in mastering writing techniques, so the students need to be aware of writing as a process and as a product as well (Okasha \& Hamdi, 2014).

Today's most prevalent writing instruction methodologies tend to emphasize the writing process and largely overlook the issue of written corrective feedback as a means to improve second language (L2) writers' grammatical accuracy and their corresponding abilities to produce linguistically accurate writing. Providing written corrective feedback on students' writings has become one of the most challenging tasks for English language teachers and is as a crucial part of the learning process (Pawlak, 2014:1; Hardi, 2020). Since the appearance of the process approach as a new means of teaching writing, teacher written corrective feedback has been highlighted as a major component of that process. Its role is viewed not only as a means to inform students about their errors, but has also been viewed as a means of channelling reactions and advice to facilitate improvement (Seker \& Dincer, 2014). Because of its significant role on students' improvement, (Salimi, 2015) argues that the written corrective feedback that teachers provide on their students' writing should be more than marks on a page. Errors serve as an important means for teachers to observe the students' learning process. It means that teachers have a great deal of attention to error in their response to students' writing (Bitchener \& Ferris, 2012;34). In this sense, corrective feedback can impact student writers' acquisition of specific language structures over time.

Corrective feedback is common in L2 and may indeed be necessary for most learners to ultimately reach native-like levels of proficiency when that is the desired goal. Written production and feedback are of special importance for second language acquisition. Norouzian (2012) posits that the main purpose of providing feedback on student errors in writing are to, as follows (1) increase student awareness of errors, (2) help students avoid the same errors/learn from the errors, (3) help students improve their writing, (4) help students correct errors, (5) give students encouragement, (6) learn how to express ideas / write better, (7) learn grammar/cohesion/coherence, (8) help students reflect on their writing, (9) help students locate their errors, and (10) long-term benefits-e.g., promoting self-learning.

Responding to students' grammatical correction in writing, a variety of corrective feedback types can be employed to improve students' awareness on errors. There are a range of variant styles of feedback (and a mixture of overlapping terminology) which have been tested for corrective feedback, direct vs. indirect (Eslami, 2014), direct vs. metalinguistic (Saadi \& Saadat, 2015), and focused vs unfocused (Kassim \& Ng, 2014). To prove the range of corrective feedback, Leki and Raimes (in Bitchener et al., 2005) posit that to give feedback is one of the important methods in helping the students improve their writing pieces. Hence, teachers have a great deal of attention to error in their response to students' writing (Bitchener \& Ferris, 2012;34). Teachers' time in providing corrective feedback is not wasted and that students will benefit more from the corrections (Ferris, 2011;93). Corrective feedback aims at encouraging the development of students' writing and is regarded as critical improving and consolidating learning. So, error correction supposedly assists the students to induce or figure out the right form of a rule. If, for example, a student writes I goes to school every day, and the teacher corrects it, the student is supposed to realize that the $/ s$ / ending goes with the third person and not the first person, and alter his or her conscious mental representation of the rule. 
621 The Effect of Indirect Coded Versus Indirect Non-Coded Corrective Feedback on Improving Students'

Grammatical Accuracy of EFL Writing Class-Maksimilianus Doi, Fransiskus M. Separ, Febe F. Irawati Wanggai

DOI: https://doi.org/10.31004/edukatif.v3i2.365

Corrective feedback given can be either direct or indirect. Direct corrective feedback occurs when a correction is provided by the teacher. It is a correction that not only calls attention to the error, but also provides a specific solution to the problem (Ferris, 2011;148). This type of written corrective feedback might more properly be called 'editing' and observed that direct direction, it is the sole form of written corrective feedback, may be frustrating to teachers and demoralizing to students. Besides, indirect feedback includes indirect coded feedback that the error type is also identified and coded and indirect non-coded that the error itself is identified through highlighting or underlining. These different and varying levels of feedback strategies are described that coded occurs when the teacher marks the error with a code (for instance, WO refers to word order, $A R T$ refers to article; non-coded error correction requires the teachers to just highlight (with a highlighter or underlining with a pen) the error without providing specific identification of what type of error has occurred.

Through these two types of indirect feedback, coded and non-coded, the learners are provided with ample time to correct their own errors. The advantage of coded feedback is that the error codes provide a common ground for teachers and students to discuss errors (Rizkiani et al., 2019)(Rizkiani et al., 2019)(Rizkiani et al., 2019)(Rizkiani et al., 2019)(Rizkiani et al., 2019). On the other hand, the advantages of non-coded feedback are to lead students to correct revision and potentially more long-term improvement (Bankier, 2012). Consequently, the effect of these types of feedback, cognitively, enables students' awareness to self-correct and edit errors, and may serve the short-term improvement (Wang \& Jiang, 2015; Khanlarzadeh \& Nemati, 2016) and the long-term improvement (Sermsook et al., 2017) of fostering student autonomy in monitoring their own writing.

Ferris (2011) argues that indirect feedback is more helpful to students' writing because it leads to greater cognitive engagement, reflection, and problem-solving. From a pedagogical perspective, it is an important component of form-focused instruction and it is advocated as effective for L2 teaching. The superiority of indirect error feedback is to indicate that an error has been made through circling, underlining, highlighting, or otherwise marking an error at its location in a sentence with or without a verbal rule reminder or an error code and asking students to make correction themselves. Seiffedin (2017) claims that indirect feedback forces students to be more reflective and analytical about their errors than if they simply transcribe teacher corrections (direct feedback) into text draft of their papers. Since students are required by indirect feedback to take more responsibility for their errors, they are likely to learn more from the process, acquire the troublesome structures, and make long-term progress in finding, correcting, and eventually avoiding errors (Ferris, 2011;33).

Referring to the attempts of mastering grammar accurately in writing, teachers have commonly provided insights that the product approach which dominates the writing teaching language scene has contributed to the deterioration in the quality of writing. Teachers avoid emphasizing on the process of writing. The teaching of writing is carried out in the most disappointing and discouraging manner. Writing is often writing to learn the language rather than learning to write, i.e. writing as a channel rather than a goal. Moreover, in-use methodology of making corrections of errors does not come-up to the level of standard evaluation/assessment. Another major problem found in an English written task by students is negative transference of their mother tongue into English. As a result, it is common for students who have been studying English for several years to have difficulties carrying on writing without making several serious grammatical errors. As mentioned above, errors found in students' writing can persist over time. Consequently, teachers even just lament the sloppiness of grammatical problems in writing without finding out the expected methods in error correction to be out of those matters.

The above-stated explanation denotes that the issue of correcting students' errors is an essential factor in effective and accurate writings. Thus, error correction and grammar instruction are major; perhaps even the 
622 The Effect of Indirect Coded Versus Indirect Non-Coded Corrective Feedback on Improving Students' Grammatical Accuracy of EFL Writing Class-Maksimilianus Doi, Fransiskus M. Separ, Febe F. Irawati Wanggai

DOI: https://doi.org/10.31004/edukatif.v3i2.365

primary, components of writing instruction in EFL writing class. By writing, it also allows greater focus on accuracy since students have the time to reflect, correct, discard, and add. This is the reason why grammar correction has received so much attention on the part of teachers because grammar is the infrastructure of the writing, and if it is weak, then a clever superstructure of ideas will simply make the whole writing collapse. Therefore, in compliance with the explanation before, the research emerges four formulated purposes that are to investigate (1) indirect coded $\mathrm{CF}$ and indirect non-coded $\mathrm{CF}$ that have a significant difference of effectiveness on improving grammatical accuracy with self-editing in the second draft of EFL student's writing under teachers' correction, (2) the effectiveness of using indirect coded CF, indirect non-coded CF, and that of control group on improving grammatical accuracy with self-editing in the second draft of EFL student's writing under teachers' correction, a new piece of EFL students' writing, (3) indirect coded CF and indirect non-coded CF that have a significant difference of effectiveness on improving grammatical accuracy in a new piece of EFL students' writing, and (4) the effectiveness of using indirect coded CF, indirect coded $\mathrm{CF}$, and that of control group on improving grammatical accuracy in a new piece of EFL students' writing.

As the consequences of having this current research, it is indicative of fact that errors are unavoidable to the students themselves that the process of making errors is as a devise the students use in order to learn. Errors tell the teachers when undertaking a systematic analysis how far toward the goals the students have progressed and what remains for students to learn. Teachers attain benefit from students' errors because errors provide feedback (Amara, 2015; Hasbemifardnia et al., 2019) and they inform teachers about the effectiveness of their teaching materials and techniques. It is fruitful for teachers to know that their students have not mastered yet certain forms of grammar. This intends to make available to teachers some of the scholarly literature detailing corrective feedback: how it is perceived and analyzed. By concisely presenting the field research, teachers will hopefully come away with an awareness of the implications which grammar correction holds for the classroom of EFL students.

\section{RESEARCH METHOD}

This research used quantitative approach by examining the relationship among variables. These variables, in turn, can be measured, typically on instruments, so that numbered data can be analyzed using statistical procedures (Creswell, 2013;4). The research was implemented at the fourth semester students of English Literature Study Program, Flores University in Academic Year of 2019/2020. The population in this quasi experimental research included 54 students majoring at English Letters Study Program in Flores University. The students were in three intact classes (A, B, C) with 18 students of each class. Three periods including pre-experiment, experiment, and post-experiment were adopted. Free writing with seven different topics was independently selected and students were requested to write one topic in class, by hand, with a time limit of 45 minutes. After having treatment, the students were given post-test. In this session, there were two tests as immediate and delayed post-test. A week after treatment, students were in immediate post-test. Students' first drafts of writing in pre-test were given back under correction. These drafts had certainly been corrected using two different corrective feedbacks for two experimental groups, and no such feedback for control group. These tasks were served as the students' writing improvement on grammar accuracy with selfcorrection/editing strategy. In delayed post-test, the students were requested to write, by hand, a new piece of writing referring to the seven different topics posited in pre-test. The data of the research were gained from those tests and analysed afterwards.

In order to enable students' self-correction for indirect coded corrective feedback, error types were introduced to students prior to their involvement with the writing test for codification of errors. The chosen labels for coding the errors were modified from (Hartshorn \& Evans, 2012). 
623 The Effect of Indirect Coded Versus Indirect Non-Coded Corrective Feedback on Improving Students' Grammatical Accuracy of EFL Writing Class-Maksimilianus Doi, Fransiskus M. Separ, Febe F. Irawati Wanggai

DOI: https://doi.org/10.31004/edukatif.v3i2.365

Table.1 Table of Common Editing Symbols for Indirect Coded CF

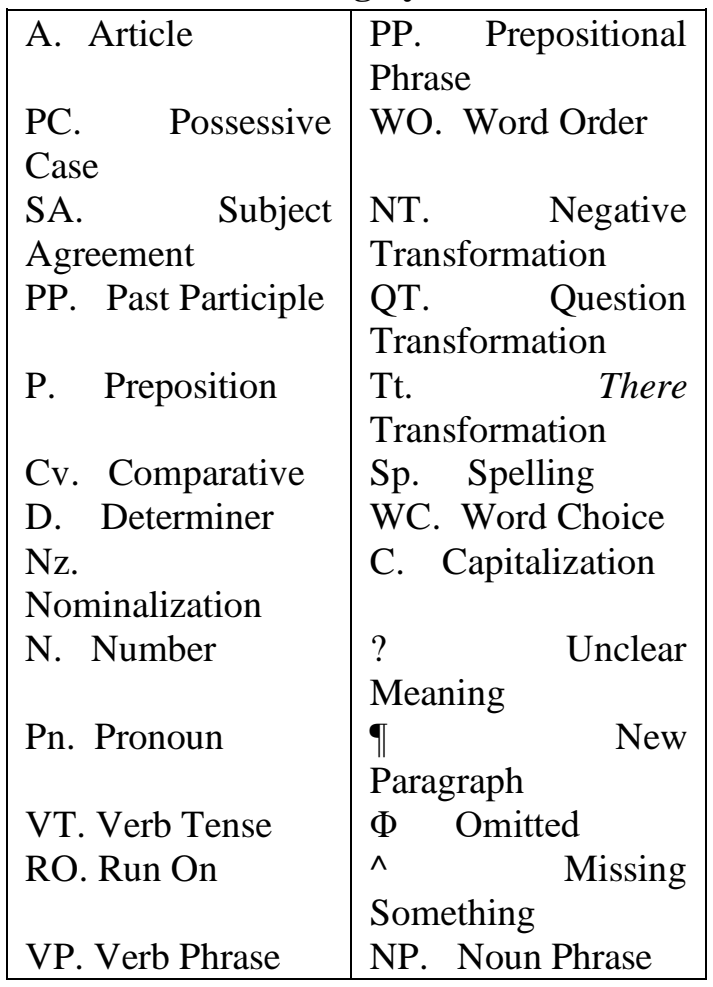

The instrument was writing assignments and observation sheet. Students' writings, as assignment, were based on seven different given topics belonging to measure students' improvement at each phase of tests referring to grammatical accuracy. The available observation sheet was intended to observe the administration of the research whether or not it ran based on the master plan of the research. In order to evaluate the writing performance of the students with regard to free writing, the scoring scheme proposed by (Jacob et al, in ARSLAN, 2014) was adopted. This analytical scheme assessed writing on the basis of five broad categories; content (30), organization (20), vocabulary (20), language use (20), and mechanics of writing (10). The scale based on which the students' written composition were scored is set at 100 .

The validity of an instrument is the degree to which an instrument measures what it is intended to measure (Pilot \& Hungler, in Sawalmeh, 2013). The reliability of the research instrument was measured by testing inter-rater. The results of Inter-rater assessment were then analysed by Product Moment correlation technique to determine the correlation coefficient between the two inter-raters. Once the coefficient is computed, $\rho>0$ will indicate positive relationship, $\rho<0$ will indicate negative relationship, while $\rho=0$ indicates non-existence of any relationship. Data obtained from pre-test and two post-test for control group and two experiment groups were analysed descriptively and quantitatively. The computation of descriptive analysis used computer-aid program of Microsoft Excel and SPSS 17 for windows. The collected data adopted a fivepoint scale with five broad categories to evaluate students' improvement in grammatical accuracy. The range of score is settled at $0-100$. To determine the criteria for the results of the tests, ideal mean $(\bar{X})$ and ideal standard deviation $\left(\mathrm{S}_{\mathrm{i}}\right)$ is the total of $\bar{X}_{\mathrm{I}}$ that is $60 \%$ of maximum score, while the total of $\mathrm{S}_{\mathrm{i}}$ is a quarter of $\bar{X}_{\mathrm{i}}$. If the maximum score of $100, \bar{X}_{\mathrm{i}}$ is $60 \%$ x $100=60$, whereas $\mathrm{S}_{\mathrm{i}}$ is $60: 4=15$. $(\mathrm{s}=60: 4=15)$.

The normality of the test referring to grammatical accuracy scores is statistically assessed using Lillefors significance correlation based on Kolmogorov-Smirnov ( $K-S$ test) with the significance value is $\alpha=0.05$; if sig. $>0.05$, data distribution is normal. The homogeneity of variance is used to examine whether the three groups are homogeneous or not, and Levene test in SPSS is used. This case is tested in common 
624 The Effect of Indirect Coded Versus Indirect Non-Coded Corrective Feedback on Improving Students' Grammatical Accuracy of EFL Writing Class-Maksimilianus Doi, Fransiskus M. Separ, Febe F. Irawati Wanggai

DOI: https://doi.org/10.31004/edukatif.v3i2.365

variants based on the hypothesis if the value of a sig or significance value $<0.05$, the three variants are not homogeneous, and if a significance value $>0.05$, the three variants are identical or homogeneous.

In this research, a statistical technique used was an analysis of covariance (ANCOVA) continued by post hoc scheffe analysis that was intended to answer research questions of 2 and 4). An alpha level of .05 is set. SPSS 17 was used to perform the analysis. The hypothesis criteria in this current research was that if $\alpha=$ $0.05<$ sig., or sig. $>0.05$, then the implication of indirect non-coded CF and coded CF is ineffective. In contrast, the use of indirect non-coded CF and coded CF on improving grammatical accuracy is effective if $\alpha=$ $0.05>$ sig., or sig. $<0.05$.

\section{RESULTS AND DISCUSSIONS}

This current research is intended to investigate the difference of effectiveness of using indirect coded and indirect non-coded corrective feedbacks on improving grammatical accuracy in students' writing. There are four distinct headings the researcher presents.

The Difference of Effectiveness Using Indirect Coded CF and Indirect Non-Coded CF on Improving Grammatical Accuracy with Self-Editing in the Second Draft of EFL Student's Writing under Teachers' Correction

Written corrective feedback is an essential aspect of any English language writing course. This is especially true now with the predominance of the process approach to writing that requires some kinds of corrective feedbacks, usually the teachers, on student drafts. Teachers need to develop more systemized and consistent forms of corrective feedback that take advantage of the process approach and make it clear to students what the feedback means and what they are to do with it. Moreover, teachers need to familiarize and train students in how to effectively use the corrective feedback in order to make gains in students' proficiency and competence as English writers.

Aside from the aforementioned effectiveness of marking errors for student self-correction, indirect coded $\mathrm{CF}$ and indirect non-coded $\mathrm{CF}$ on grammar can be productive in improving students' writing skills. To lessen student confusion, teachers should consistently use a standard set of symbols or cycles to indicate place and type of error and train the students in what kinds of corrections to make based on each symbol/cycle. Furthermore, teachers should familiarize students with the system so they will not be surprised when new symbols occur.

Referring to indirect corrective feedback employed in the current research with indirect coded $\mathrm{CF}$ and indirect non-coded CF, students get different gains as a last resort of their achievement in writing skill. As stated earlier, to come up with a satisfactory answer to the first research question, a comparison of different effect is required to be made between the self-correction ability of two indirect corrective feedback groups and that of control group. The difference of effectiveness of using indirect corrective feedback on improving grammatical accuracy in students' self-editing in the second draft of EFL student's writing under teachers' correction performs proves that pre-test has a significant effect to immediate post-test. The upshots of students' grammatical accuracy improvement with self-editing in the second draft in immediate post-test are not only influenced by treatment, but also by the initial performance in pre-test. The differences of treatment simultaneously affect students' scores in immediate post-test whose F-value is 34.639 with sig. $<0.05$ $(0.000<0.05)$. As conclusion, two different treatments of two kinds of indirect corrective feedback, and that of control group have a great difference of effectiveness on improving students' grammatical accuracy with selfediting strategy. 
625 The Effect of Indirect Coded Versus Indirect Non-Coded Corrective Feedback on Improving Students' Grammatical Accuracy of EFL Writing Class-Maksimilianus Doi, Fransiskus M. Separ, Febe F. Irawati Wanggai

DOI: https://doi.org/10.31004/edukatif.v3i2.365

\section{The Effectiveness of Using Indirect Coded CF and Indirect Non-Coded CF, and that of control group on Improving Grammatical Accuracy with Self-Editing in the Second Draft of EFL Student's Writing under Teachers' Correction}

(Bitchener \& Ferris, 2012:157) posit that students can benefit from receiving tools and opportunities to self-edit their texts. Tools for self-editing can provide their students to develop better self-editing skills with written corrective feedback that not only impact the text under immediate consideration but which build skills and awareness for subsequent writing tasks. An opportunity for self-editing provides students the ways they construct their writing course and assignments. It is explicitly supported by (Savage et al., 2010:3) that most EFL students expect teachers to correct their grammar errors, but a more practical goal is for students to learn to correct their own errors. The ability to self-correct is particularly desirable for students with job-related or educational goals.

In line with the statement above, the difference of effectiveness of using indirect corrective feedback on improving grammatical accuracy is performed in two parts of explanation, i.e., the difference of effectiveness using indirect non-coded CF and Coded CF on Students' self-editing in the second draft of EFL student's writing under teachers' correction.

The Effectiveness of Using Indirect Coded CF on Students' Self-Editing in the Second Draft of EFL Student's Writing under Teachers' Correction

After giving treatment in class $\mathrm{C}$ at the fourth semester students of English Letters Study Program with 8 successive meetings, the upshot of students' improvement with self-editing strategy in the second draft of writing indicates that indirect coded $\mathrm{CF}$ group has acted better that the other two groups have, i.e. indirect non-coded and control groups occurred in immediate post-test. The mean difference of immediate post-test gained is 78.67 with minimum score is 69 and maximum score is 86 . To come up with a comparison between the self-correction ability of indirect coded CF group and that of control group, a partial amount of difference of two groups on the second draft is denoted in line with the upshot of post hoc scheffe analysis that the difference between the two groups concerning their self-correction ability is significantly different since the $p$ value is less than 0.05 . The mean difference between coded CF group and control group is 12.833 with $p$ value of 0.000. On the other side of it, the comparison of mean difference between coded CF and non-coded $\mathrm{CF}$ groups is 5.056 with $p$-value of 0.046 . It indicates that coded CF group has a significant difference of effectiveness on the second draft of writing with mean score of 78. 67. It proves that the improvement of grammatical accuracy in the second draft of coded CF group is much increased performed in pre-test with mean score of 68.28 .

Returning to what (Pawlak, 2014:3) states, coded correction encourage students to look at writing as a skill that can be improved, and train them in looking for areas of improvement. It is believed to be a useful method of helping students correct their own errors, as students need to be guided in discovering the nature of their errors. The indirect coding technique consists of using a number of different codes (in the body of students' paper) referring to the different aspects of language such, as word order, spelling, verb, tense, etc. The error codes to help students correct their writing have often been proved to be an effective method to facilitate error correction. Coded feedback points to the exact location of an error, and the type of error involved is indicated with a code or a teacher's cue.

The Effectiveness of Using Indirect Non-Coded CF on Students' Self-Editing in the Second Draft of EFL Student's Writing under Teachers' Correction

In brief, the current research reveals that indirect non-coded CF can affect students' ability in selfediting applied in the second draft of writings administered in immediate post-test. After having treatment, students tend to improve their accuracy in grammar because the clues given by underlining/cycling the errors exist help them recognize what they have made in writing. To prove their improvement, immediate post-test is 
626 The Effect of Indirect Coded Versus Indirect Non-Coded Corrective Feedback on Improving Students' Grammatical Accuracy of EFL Writing Class-Maksimilianus Doi, Fransiskus M. Separ, Febe F. Irawati Wanggai

DOI: https://doi.org/10.31004/edukatif.v3i2.365

administered after treatment. However, non-coded CF group as the first experiment group has cognitively contributed to students' improvement in writing. The upshot of immediate post-test, in non-coded CF group, shows the mean score of 73, 61 with minimum score of 59 and maximum score of 85 . Belonging to multiple comparison of post hoc scheffe analysis, the comparison of mean difference between non-coded CF group and control group in the second draft of students' writing is 7.778 with significance value of 0.001 . For non-coded CF group and coded group, mean difference gained is -5.506 with significance value of 0.046 . Additionally, the mean score of non-coded CF group is 73.61 that is much improved from the mean score of 67.67 in pretest.

Clearly, indirect non-coded CF group has a significant difference of effectiveness on the improvement of grammatical accuracy with self-editing/correction in the second draft of writing. Indirect non-coded feedback is merely error identification, but in each case leaves the student to diagnose and correct the error (Lee, 2020) The result of the research is in line with those of (Akkuzu, 2014) and (Bitchener \& Ferris, 2012) who come up with positive effect of feedback on students' written production that indirect non-coded feedback caters to guided learning and problem solving and encourages students to reflect about linguistic forms. For these reasons, it is considered more likely to lead to long-term learning.

In summarizing two distinct headings explained above, it is indicative of fact that indirect coded $\mathrm{CF}$ is more effective than the use of indirect non-coded CF whose mean difference is 5.056 with sig. $<0.0 .05$ $(0.000<0.05)$ and that of control group whose F-value is 12.833 with sig. $<0.05(0.000<0.05)$. The research findings also corroborate those of (Buckingham \& Ekinci (2017) saying that indirect coded corrective feedback helps learners make fewer errors. It is also in compliance with (Salimi, 2015) saying that students typically have a strong desire to improve the accuracy of their text if they know that these will be shared later on. This follow-on accuracy work, or editing, is the process whereby the students themselves, other students, and /or/ teachers read their written work and suggest changes which can be incorporated in a new version of that work. Editing takes places either while students are writing or after the students have finished. Editing is important since it increases students' awareness of appropriate forms.

The difference of Effectiveness Using Indirect Coded CF and Indirect Non-Coded CF on Improving Grammatical Accuracy in a New Draft of EFL Students' Writing

According to (Bitchener \& Ferris, 2012;144), the main question of research into written corrective feedback is cognitive. Researchers would like to determine the degree to which written corrective feedback can contribute to the acquisition of a second language; in other words, they are interested in the effect of written corrective feedback on short-term and long-term memory. Jamalinesari et al. (2015) who investigate the influence of the second language writing on the learning of knowledge in the short-term memory find that after written corrective feedback the number of errors in the new written texts have been reduced.

Based on the result of computation with SPSS 17 for windows gains a significance level of 0.000 that is less than $0.05(0.000<0.05)$. It means that pre-test in control group and experimental groups have a significant effect whose F-value is 16.781 with sig. $<0.05(0.000<0.05)$. The initial performance of avoiding grammatical errors in students writing in pre-test has cognitively influenced to delayed post-test. In contrast, the different treatments conducted separately in three intact classes have a different effect on students' improvement in a new draft of students' writing whose F-value is 54.034 with sig. $<0.05(0.000<0.05)$. This computation covers a conclusion that indirect coded CF and Indirect non-coded CF have a significant difference on improving students' grammatical accuracy in a new draft of writing.

The Effectiveness Using Indirect Coded CF, Indirect Non-Coded CF, and that of control group on Improving Grammatical Accuracy in a New Draft of EFL Students' Writing 
627 The Effect of Indirect Coded Versus Indirect Non-Coded Corrective Feedback on Improving Students' Grammatical Accuracy of EFL Writing Class-Maksimilianus Doi, Fransiskus M. Separ, Febe F. Irawati Wanggai

DOI: https://doi.org/10.31004/edukatif.v3i2.365

In this part, there are two different points of view the researcher prescribes. It belongs to the explanation regarding to the effects of indirect corrective feedback on improving grammatical accuracy in a new draft of students' writing.

The Effectiveness of Using Indirect Non-Coded CF on Improving Grammatical Accuracy in a New Draft of EFL Students' Writing

The comparison of performing students' writing on improving grammatical accuracy in delayed posttest shows that non-coded CF group has mean difference of 79.61 with minimum score of 67 and maximum score of 88. Reflecting on what the results of students' writing gained in reference to the improvement of grammatical accuracy in a new draft of writing, it can be inferred that the interval score between control group and non-coded CF group is 12.17; and the interval score between non-coded CF group and coded CF group is 4.5. In tandem with the gained upshots through running post hoc scheffe analysis, it indicates that indirect noncoded CF group students are characterized by a significant difference of effectiveness on improving grammatical accuracy compared with control group that has mean difference of 12.167 with $p$-value of 0.000 . On the other side, in tandem to coded CF group, non-coded CF group has mean difference of -4.500 with $p$ value of 0.041. After having treatment, it is indicative of the fact that the mean score of this group improves significantly with mean score of 79.61. It is much improved from the mean score of 73.61 in immediate posttest. This upshot of the research can be considered that the provision of indirect non-coded CF to the students can significantly affect the performance of students' grammatical accuracy in a new draft of writing.

The Effectiveness of Using Indirect Coded CF on Improving Grammatical Accuracy in a New Draft of EFL Students' Writing

The research investigates that indirect coded corrective feedback is effective on improving students' grammatical accuracy in a new draft of writing. The indication of this statement can be proven by the mean score of delayed post-test compared to two different groups, i.e., non-coded CF and control groups. Students' performance on improving grammatical accuracy of indirect coded CF group in a new draft of writing has acted better compared to two different groups, i.e. indirect non-coded and control groups. Based on the result of delayed, the mean score of this phase is 84.11 with minimum score of 72, and maximum score of 94, and a standard deviation is 5.940. Post hoc scheffe analysis performs that there is a significant difference between two indirect corrective feedback groups and control group. The comparison between coded CF and control groups is shown by mean difference of 16.667 with $p$-value of 0.000 ; coded CF and non-coded CF groups have mean difference of 4.500 with $p$-value of 0.041 . Returning to the computation indicated above, it denotes that coded CF has a significant difference of effectiveness on improving grammatical accuracy in a new draft of EFL students' writing.

To sum up the two distinct headings prescribed above, it denotes that both indirect coded $\mathrm{CF}$ and indirect non-coded CF have a significant difference of effectiveness. In tandem with the gained upshots through running post hoc scheffe analysis, it indicates that indirect coded CF is more effective than the use of indirect non-coded CF whose F-value is 4.500 with sig. $<0.05(0.041<0.05)$, and that of control group whose F-value is 16.667 with sig. $<0.05(0.000<0.05)$ on improving students' grammatical accuracy in a new draft of writing.

\section{CONCLUSION}

In compliance with the research questions, as conclusion, it can be inferred that (1) indirect non-coded and indirect coded corrective feedback have a significant difference of effectiveness on improving grammatical accuracy with self-editing in the second draft of EFL student's writing under teachers' correction whose F-value is 34.639 with sig. $<0.05(0.000<0.05)$; (2) there is a significant difference of effectiveness of 
628 The Effect of Indirect Coded Versus Indirect Non-Coded Corrective Feedback on Improving Students' Grammatical Accuracy of EFL Writing Class-Maksimilianus Doi, Fransiskus M. Separ, Febe F. Irawati Wanggai

DOI: https://doi.org/10.31004/edukatif.v3i2.365

using indirect coded $\mathrm{CF}$ and indirect non-coded $\mathrm{CF}$, and that of control group on improving grammatical accuracy with self-editing in the second draft of EFL student's writing under teachers' correction. It is indicative of fact that indirect coded CF is more effective than the use of indirect non-coded $\mathrm{CF}$ whose mean difference is 5.056 with the significance level of $0.046(\mathrm{p}<0.05)$; and that of control group whose mean difference is 12.833 with the significance level of $0.000<0.05$; (3) Indirect coded CF and indirect non-coded $\mathrm{CF}$ have a significant difference of effectiveness on improving grammatical accuracy in a new draft of writing whose F-value is 54.034 with sig. $<0.05(0.000<0.05)$; (4) there is a significant difference of effectiveness of using indirect coded $\mathrm{CF}$, indirect non-coded $\mathrm{CF}$, and that of control group on improving grammatical accuracy in a new draft of student's writing. It is indicative of fact that indirect coded CF is more effective than the use of indirect non-coded CF whose mean difference is 4.500 with the significance level of 0.041 ; and that of control group whose mean difference is 16.667 with the significance level of 0.000 .

\section{THANKSGIVING}

The outcomes accessed through the current scrutiny are liable to present manifold implications mainly for teachers and students. Teachers should take interest in line of overall linguistic inaccuracies by utilizing written corrective feedback to guide students' writing improvement on grammar accuracy with selfcorrection/editing strategy. In having this, the sincere gratitude unforgettably goes to those who have supported the administration of the current research. They are Dean of Faculty of Language and Literature, Chair of English Literature Study Program giving the valuable chance to conduct the research. Also, many thanks are addressed to all students of the fourth semester who have had an opportunity to cooperatively participate the implementation of the current research.

\section{REFERENCES}

Akkuzu, N. (2014). The role of different types of feedback in the reciprocal interaction of teaching performance and self-efficacy belief. Australian Journal of Teacher Education, 39(3), 37-66.

Amara, N. (2015). Errors Correction in Foreign Language Teaching. The Online Journal of New Horizons in Education, 5(3), 58-68.

ARSLAN, R. Ş. (2014). Integrating feedback into prospective english language teachers' writing process via blogs and portfolios. TOJET: The Turkish Online Journal of Educational Technology, 13(1), 131150 .

Ayuba, H., \& Widodo, P. (2015). Pengembangan Tes gramatika berbasis Web untuk Mahasiswa Pendidikan Bahasa Inggris IAIN Sultan Amai Gorontalo. LingTera, 2(3), 111-121.

Bankier, J. (2012). Post-Text and In-Text Corrective Feedback. Language Education, 3(1), 85-95.

Bitchener, J., \& Ferris, D. R. (2012). Writtem Corrective Feedback in Second Language Acquisition and Writing. New York: Routledge. https://doi.org/10.14706/jeh2019213

Bitchener, J., Young, S., \& Cameron, D. (2005). The effect of different types of corrective feedback on ESL student writing. Journal of Second Language Writing, 14(3), 191-205.

Creswell, J. W. (2013). Research Design; Qualitative, Quantitative, and Mixed Method Approaches. (Fourth Edi). Lonson: Sage Publications, Inc.

Eslami, E. (2014). The Effects of Direct and Indirect Corrective Feedback Techniques on EFL Students Writing. Procedia - Social and Behavioral Sciences, 98, 445-452.

Ferris, D. R. (2011). Treatment of Error in Second Language Student Writing. University of Michigan: 
629 The Effect of Indirect Coded Versus Indirect Non-Coded Corrective Feedback on Improving Students' Grammatical Accuracy of EFL Writing Class-Maksimilianus Doi, Fransiskus M. Separ, Febe F. Irawati Wanggai

DOI: https://doi.org/10.31004/edukatif.v3i2.365

University of Michigan Press.

Foin, A. T., \& Lange, E. J. (2007). Generation 1.5 Writers' Success in Correcting Errors Marked on an Outof-Class Paper. The CATESOL, 19(1), 146-163.

Hardi, V. A. (2020). The Rules of Feedback in Writing Class. Edukatif: Jurnal Ilmu Pendidikan, 2(3), 244252.

Hartshorn, K. J., \& Evans, N. W. (2012). The Differential Effects of Comprehensive Corrective Feedback on L2 Writing Accuracy. IRAL - International Review of Applied Linguistics in Language Teaching, 9(4), 319-334.

Hasbemifardnia, A., Namaziandost, E., \& Sepehri, M. (2019). The effectiveness of giving grade , corrective feedback, and corrective feedback-plus-giving grade on grammatical accuracy. International Journal of Research Studies in Language Learning, 8(1), 15-27.

Jamalinesari, A., Rahimi, F., Gowhary, H., \& Azizifar, A. (2015). The Effects of Teacher-Written Direct vs. Indirect Feedback on Students' Writing. Procedia - Social and Behavioral Sciences, 192, 116123.

Kassim, A., \& Ng, L. L. (2014). Investigating the Efficacy of Focused and Unfocused Corrective Feedback on the Accurate Use of Prepositions in Written Work. 7(2), 119-130.

Khanlarzadeh, M., \& Nemati, M. (2016). Language Teaching Research The effect of written corrective feedback on grammatical accuracy of EFL students : An improvement over previous unfocused designs. Language Teaching Research, 4(2), 55-68.

Larasati, M. M. B. (2021). Kemampuan Menulis Naskah Drama Pentas dengan Menggunakan Media Cerita Rakyat Pada Siswa Sekolah Menengah Atas. Edukatif: Jurnal Ilmu Pendidikan, 3(2), 376-384.

Lee, Y.-J. (2020). The long-term effect of automated writing evaluation feedback on writing development. English Teaching, 75(1), 67-92.

Norouzian, R. (2012). Written Error Feedback from Perception to Practice : A Feedback on Feedback. 3(1), $11-22$.

Okasha, M. A., \& Hamdi, S. A. (2014). Using strategic writing techniques for promoting EFL writing skills and attitudes. Journal of Language Teaching and Research, 5(3), 674-681.

Pawlak, M. (2014). Second Language Learning and Teaching : Error Correction in the Foreign Language Classroom. Heiderlberg: Springer.

Rizkiani, S., Bhuana, G. P., \& Rizgiya, R. S. (2019). Coded vs Uncoded corrective Feedback on Teaching Writing Descriptive Tect. ELTIN, 8(1), 55-66.

Saadi, Z. K., \& Saadat, M. (2015). Iranian EFL Learners' Grammatical Knowledge : Effect of Direct and Metalinguistic Corrective Feedback. 8(8), 112-120. https://doi.org/10.5539/elt.v8n8p112

Salimi, A. (2015). The Effect of Coded and Uncoded Written Corrective Feedback on the Accuracy of Learners Writing in Pre-intermediate Level. 4(3). https://doi.org/10.7575/aiac.ijalel.v.4n.3p.116

Savage, K. L., Bitterlin, G., \& Price, D. (2010). Grammar matters: Teaching Grammar in Adult ESL Programs. In Cambridge University Press. New York: Cambridge University Press.

Sawalmeh, M. H. M. (2013). Error Analysis of Written English Essays: The case of Students of the Preparatory Year Program in Saudi Arabia. Journal of English for Academic Purposes, 14(40), $1552-1557$.

Seiffedin, A. H. (2017). The Impact of Direct-indirect Corrective E- feedback on EFL Student s' Writing Accuracy. Theory and Practice in Language Studies, 7(3), 166-175.

Seker, M., \& Dincer, A. (2014). An insight to students' perceptions on teacher feedback in second language 
630 The Effect of Indirect Coded Versus Indirect Non-Coded Corrective Feedback on Improving Students' Grammatical Accuracy of EFL Writing Class - Maksimilianus Doi, Fransiskus M. Separ, Febe F. Irawati Wanggai

DOI: https://doi.org/10.31004/edukatif.v3i2.365

writing classes. English Language Teaching, 7(2), 73-83. https://doi.org/10.5539/elt.v7n2p73

Sermsook, K., Liamnimitr, J., \& Pochakorn, R. (2017). The Impact of Teacher Corrective Feedback on EFL Student Writers' Grammatical Improvement. English Language Teaching, 10(10), 43-49.

Wang, T., \& Jiang, L. (2015). Studies on Written Corrective Feedback: Theoretical Perspectives , Empirical Evidence , and Future Directions. English Language Teaching, 8(1), 110-120. https://doi.org/10.5539/elt.v8n1p110 